\title{
Research on the ecological consumption education in Colleges and universities from the perspective of College Students' Consumption Psychology
}

\author{
Liying Yin \\ Jilin Agricultural University, Changchun 130118, China \\ ylyjlnd@126.com
}

Keywords: College Students, Consumption Psychology, Ecological Consumption, Education, Way.

\begin{abstract}
Based on the existence of different degrees of college students blind consumption, comparisons of consumption, pleasure consumption, sports consumption and other immature consumer psychology, leading to waste, pollution, consumer behavior and irrational consumption structure and other "non-ecological" consumer behavior, by paying attention to the mental health of college students, improve the ability of psychological regulation; to establish the ecological value of consumption, college students "financial business"; strengthen the routine management of the school, develop a reasonable consumption habits; play a fundamental role in family education, the students' improper spending control and other aspects, put forward ways of College Students' ecological consumption education.
\end{abstract}

\section{Introduction}

Consumer psychology refers to a series of psychological activities and psychological characteristics of consumers in the consumption activities, including consumer interest, consumption habits, values and other aspects. Healthy consumption psychology is a necessary component of health psychology, which has a positive impact on consumer behavior. Because of the college students are in the world view values formation, in upholding materialism values under the influence of the material consumption as a status symbol, regard happiness as the satisfaction of material needs; the lack of care and ecological consumption education and college parents " Practise thrift at home but be amply provided while traveling", not mature consumer psychology has come, and the consumption behavior.

Ecological consumption is a kind of safe and healthy, moderate and reasonable consumption mode, which not only meet the material and cultural needs of mankind, but also conducive to resource conservation and environmental protection;

It can not only meet the needs of contemporary people, but also do harm to the future generations. It has the characteristics of moderate, comprehensive, environmental protection and sustainability. Therefore, based on the college students is not mature and consumer psychology, analysis of college students "non ecological" consumption behavior, ecological consumption education, aimed at college students the way of ecological consumption education suggestions are put forward.

\section{The basic conditions of college students' consumption and consumption psychology}

Taking a college student in Changchun as the object of study, the author used the self-made questionnaire to investigate the college students' consumption psychology, and made a statistical analysis. 300 questionnaires were sent out, and the valid questionnaires were recovered by 285 . The effective rate was $95 \%$.

\subsection{The basic conditions of college students' consumption}

From table 1 and table 2, in the college students consumer groups, college students' lives by work-study programs and scholarships, $4.7 \%$ and $2.5 \%$ respectively, the vast majority of college students because of the economy has not yet independent, spending money comes mainly from their 
parents, but in consumption level, and to the rising consumption in 500-1000 yuan accounted for $63.3 \%$, more than 1000 yuan accounted for $11.2 \%$.

Table 1. Sources of college students' consumption survey statistics

\begin{tabular}{|c|c|c|c|c|}
\hline $\begin{array}{c}\text { Source of } \\
\text { consumption }\end{array}$ & $\begin{array}{c}\text { All rely } \\
\text { on parents }\end{array}$ & $\begin{array}{c}\text { Most rely } \\
\text { on parents }\end{array}$ & $\begin{array}{c}\text { Most of the work-study } \\
\text { programs of their own }\end{array}$ & $\begin{array}{c}\text { Most of the } \\
\text { scholarship }\end{array}$ \\
\hline $\begin{array}{c}\text { Number of } \\
\text { people(people) } \\
\text { Proportion(\%) }\end{array}$ & 188 & 77 & 13 & 7 \\
\hline
\end{tabular}

Table 2. Monthly consumption level of College Students

\begin{tabular}{|c|c|c|c|c|c|}
\hline $\begin{array}{c}\text { Month consumption } \\
\text { level }\end{array}$ & $\begin{array}{c}\text { Less than 300 } \\
\text { yuan }\end{array}$ & $\begin{array}{c}301-500 \\
\text { yuan }\end{array}$ & $\begin{array}{c}501-1000 \\
\text { yuan }\end{array}$ & $\begin{array}{c}1001-1500 \\
\text { yuan }\end{array}$ & $\begin{array}{c}\text { More than } 1500 \\
\text { yuan }\end{array}$ \\
\hline $\begin{array}{c}\text { Number of } \\
\text { people(people) }\end{array}$ & 6 & 67 & 180 & 28 & 4 \\
Proportion(\%) & 2.2 & 23.3 & 63.3 & 9.8 & 1.4 \\
\hline
\end{tabular}

\subsection{The consumption of college students mental performance}

Table 3. College students' consumption idea survey statistics

\begin{tabular}{|c|c|c|c|c|}
\hline Consumption concept & $\begin{array}{c}\text { Make ends } \\
\text { meet }\end{array}$ & $\begin{array}{c}\text { Try to be } \\
\text { frugal }\end{array}$ & $\begin{array}{c}\text { Enough money to } \\
\text { spend }\end{array}$ & $\begin{array}{c}\text { Advanced consumption } \\
\text { (borrowing) }\end{array}$ \\
\hline $\begin{array}{c}\text { Number of } \\
\text { people(people) }\end{array}$ & 165 & 53 & 36 & 31 \\
Proportion(\%) & 57.8 & 18.7 & 12.6 & 10.9 \\
\hline
\end{tabular}

As shown in table 3, although the vast majority of college students' consumption is within the scope of the economic conditions permit, the study also showed that $18.7 \%$ of college students "thrifty" as far as possible, but as material needs are met, and the influence of western consumerism, many restrictions from parents of college students, the pursuit of individual character, show individual character, there is no shortage of make track for a "new" in the university campus, there are $12.6 \%$ students the concept of "money and consumption", the lack of saving consciousness, and $10.9 \%$ of college students the concept of consumption (borrow), so, in real life there is a lot of consumer psychology conformity the pursuit of fashion and popular, with consumer psychology, hedonic consumption psychology, consumption psychology. The survey shows that some college students to have one of the most popular mobile phone, in order to hold a party in order to open up a fresh outlook, and his girlfriend had a romantic "ocean festival", they live frugally, even at the cost to borrow money, to satisfy their own desires, lack of rational consumption.

As a special consumer group of college students, although the mainstream consumer psychology is healthy, realistic, but also there are different degrees of blind consumption, comparison of consumption, hedonic consumption, conspicuous consumption, excessive consumption of immature consumer psychology.

\section{Immature consumer psychology, resulting in non ecological consumer behavior}

"The ecological consumption" is run counter to the sustainable development way of consumption, it is not in conformity with the development of the ecological production level, at the same time, meet the material and cultural needs of human waste of natural resources, destroy the ecological environment and threatened the harmony of man and nature, the harm to people's physical and mental health of consumer. This is closely related to the immature consumption psychology.

\subsection{Consumer psychology blindly, causing serious waste}

From table 4, in the college students consumer groups, although the vast majority of college students have a spending plan $(72.6 \%)$, however, there are $28.4 \%$ of college students in the process of 
consumption without a plan, after is the feeling of joy and happiness when consumer shopping, as long as the pocket money, whether need it or not, also whether is suitable for oneself, can impulse buying, also pay attention to the balance and moderation of the overhead is rare, weak financial management concepts, spending spree, poor financial management ability, blindness is very big, waste is inevitable.

Table 4. College students' consumption plan survey statistics

\begin{tabular}{|c|c|c|c|}
\hline Consumption plan & Have strict plans & Have plans & Have no plans \\
\hline Number of people(people) & 15 & 192 & 78 \\
Proportion(\%) & 5.1 & 67.5 & 27.4 \\
\hline
\end{tabular}

Table 5. The situation of the college students to save water, electricity, food survey statistics

\begin{tabular}{|c|c|c|c|}
\hline Saving consciousness behavior & often & sometime & never \\
\hline Number of people(people) & 148 & 123 & 14 \\
Proportion(\%) & 52 & 43.1 & 4.9 \\
\hline
\end{tabular}

Waste is mainly living waste. As shown in Table 5, although the vast majority of college students have the consciousness of saving and behavior accounted for more than $90 \%$, but some do not often, but there are $4.9 \%$ of the students never save consciousness and behavior. The wash when the water tap of the "waste water" phenomenon, the day and night lights in the classroom still cannot leave the classroom lights on the "waste light" phenomenon, the canteen food freely poured leftovers phenomenon It is often seen.According to estimates: if more than 200 lights a day to work for an hour, which means that every day to burn more than 10 kilograms of coal, waste about 5 tons per year of coal. Blind consumption psychology can bring waste can be imagined.

3.2 Comparison of consumer psychology, resulting in a lack of reason

Table 6. Survey and analysis of the influencing factors of College Students' consumption

\begin{tabular}{|c|c|c|c|c|c|c|}
\hline $\begin{array}{c}\text { Influence } \\
\text { factors }\end{array}$ & Media & Tradition & $\begin{array}{c}\text { Fashion } \\
\text { trend }\end{array}$ & $\begin{array}{c}\text { Family } \\
\text { consumption habits }\end{array}$ & Emotion & $\begin{array}{c}\text { Students } \\
\text { consumption }\end{array}$ \\
\hline $\begin{array}{c}\text { Number of } \\
\text { people(people) }\end{array}$ & 58 & 32 & 56 & 52 & 24 & 87 \\
Proportion(\%) & 20.4 & 11.3 & 19.7 & 18.1 & 8.5 & 30.5 \\
\hline
\end{tabular}

As shown in Table 6, the biggest influence on College Students' consumption is "student consumption", the proportion of $30.5 \%$, which is undoubtedly driven by vanity psychological comparisons produced. Due to the lack of consumer experience, especially for students from rural areas, with a superb collection of beautiful things the temptation of goods, for their own "face", also to between the city college distance, regardless of their economic conditions, from eat, wear, use, play the consumer to consumer awareness, many aspects of psychological imitation and competition. If too much imitation, comparing, consumption will lead to the lack of rational, inefficient consumption. "Just spend tomorrow's money, finish today's dream" of the consumption is true portraiture.

\subsection{Get used to "disposable" consumer psychology, resulting in environmental pollution}

Table 7. The rate of the environmental protection consciousness of college students consumption

\begin{tabular}{|c|c|c|c|c|}
\hline $\begin{array}{c}\text { Consumer } \\
\text { environmental } \\
\text { awareness }\end{array}$ & $\begin{array}{c}\text { Often use } \\
\text { disposable } \\
\text { items }\end{array}$ & $\begin{array}{c}\text { Often drink } \\
\text { bottled water }\end{array}$ & $\begin{array}{c}\text { Do not run out of } \\
\text { school supplies }\end{array}$ & $\begin{array}{c}\text { Throw away the } \\
\text { reusable daily } \\
\text { necessities }\end{array}$ \\
\hline $\begin{array}{c}\text { Number of } \\
\text { people(people) } \\
\text { Proportion(\%) }\end{array}$ & 72 & 105 & 105 & 155 \\
\hline
\end{tabular}

"Disposable products" means plastic products, wood products or paper products that can be used only once. Such as disposable lunch boxes, chopsticks and cups. One with the lost, convenient, but also eliminates the need for a lot of trouble. "Disposable products" has become a part of college students' daily life, and a one-timeconsumption becomes a habit. As shown in Table 7, "often use disposable supplies", "often buy bottled water", "books, these school supplies are not used up no longer use", "throw away reusable daily necessities" Accounting for $25.1 \%$ of the total number, 
$36.8 \%, 36.9 \%, 54.3 \%$. Behind "One - time" consumption habits is huge waste of resources. Especially plastic "Disposable products", after the difficult degradation caused by garbage disaster, increased the burden on the environment. Although the school graduation season will have a "flea market", but the consumption of college students awareness of environmental protection should be enhanced.

\subsection{Hedonic consumption psychology, making the irrational consumption structure}

Table 8 . The proportion of college students' consumption type

\begin{tabular}{|c|c|c|c|c|}
\hline Consumption Type & $\begin{array}{c}\text { Basic living } \\
\text { consumption }\end{array}$ & $\begin{array}{c}\text { Interpersonal } \\
\text { consumption }\end{array}$ & $\begin{array}{c}\text { Learning } \\
\text { consumption }\end{array}$ & $\begin{array}{c}\text { Fashion } \\
\text { entertainment } \\
\text { consumption }\end{array}$ \\
\hline $\begin{array}{c}\text { Number of } \\
\text { people(people) } \\
\text { Proportion(\%) }\end{array}$ & 180 & 89 & 108 & 78 \\
\hline
\end{tabular}

Reasonable consumption of college students should be based on basic living and learning consumption, taking into account leisure, interpersonal and other consumption.But as shown in Table 8, for the "basic living consumption", "Interpersonal consumption", "learning consumption", "fashion entertainment consumption" accounted for $63.1 \%, 31.3 \%, 37.8 \%, 27.3 \%$. It can be seen that college students pay attention to the material and entertainment consumption, and the lack of attention to the spiritual needs and development needs, the irrational consumption structure will not only adversely affect the study and life of college students, but also will increase the economic burden of the family.

\section{Methods of Ecological Consumption Education for College Students}

\subsection{Concerned about the mental health of college students to improve the ability of psychological regulation}

College students' "non - ecological" consumer behavior, external to show the psychological maturity of college students is not fully mature. The survey shows that $8.5 \%$ of college students are affected by emotions and consumption to achieve psychological compensation and substitution. Therefore, we should give play to mental health course and the role of psychological counseling, provide a psychological space for students, to help students learn to use the correct method to eliminate bad mood, to curb runaway consumption behavior, investment life with a good attitude.

\subsection{Establish the ecological consumption values, training college students "Financial business".}

First of all, popularize the knowledge of ecological consumption, establish a scientific and reasonable view of ecological consumption. To take the elective class, to infiltrate the basic knowledge of ecological consumption; to use the ideological and political theory courses for college students social responsibility and ecological awareness education, ideological and political theory content and consumer concept combined to help students establish the ecological consumption concept, So that college students to distinguish what is reasonable consumption, what is not normal consumption, to help college students solve deep-seated thinking. Secondly, increase the "financial business" of college students, and cultivate the consumption ability of college students. Financial and IQ, emotional intelligence as an indispensable modern society, the three qualities, it reflects the survival of people in the socio-economic capacity. Therefore, through the holding of financial, financial aspects of lectures, training college students "financial business" to avoid impulsive consumption caused by endless waste, so that the normal development of consumer psychology.

\subsection{Strengthen the routine management of the school, develop reasonable consumption habits}

For college "studentsnon-ecological" consumer behavior, the school to be standardized and management. First of all, the quota management of students' water and electricity; the class responsibility system of "Man walking light" to strengthen the students' consciousness of saving. Second, to carry out the ecological consumption theme practical activities Such as, to carry out the used materials recycling activities Cut use disposable goods campaigns To abandon the waste CD 
action and so on, form good consumption atmosphere on campus, the reasonable consumption habit, make rational managing concept of environmental protection of the ecological consumption become a new campus fashion

\subsection{Play the basis of the role of family education, control students inappropriate expenses.}

The survey shows that parents are the main economic source of college students' consumption, accounting for $65.8 \%$ of their total expenditure, and most of them depend on $27 \%$ of their parents. The school every semester should be a variety of normal fees, the normal level of consumption of college students and students in the school consumption situation with parents to communicate, so that parents have a good idea to be able to timely and effective control of students inappropriate expenses, to help promote immature consumer psychology and " Ecological "consumer behavior of the spread.

\section{Summary}

The survey of college students' consumption psychology shows that the psychological state of college students is generally good, but there are some students who are not mature in consumer psychology, bring risks to the mental health of college students, directly affect the consumption behavior of college students and restrict the realization of ecological consumption, and take measures to respond positively.

\section{References}

[1]. Lihua Feng, Consumer psychology, China Electric Power Press, 2010(3).

[2]. Enze Liu, an Analysis of the Restrictive Factors of College Students' Ecological Consumption, [J]. Modern Enterprise Education, 2014(22), 296-297.

[3]. Liying Yin, Reflections on the Education of College Students' Ecological Consumption, [J].Youth and society 2014(7),42-43. 